\title{
Pengaruh Brand Image Judul Program terhadap Minat Menonton Program Talkshow Tonight Show Net TV
}

\author{
Rizka Aprilliani, Muhammad Gafar Yoedtadi \\ Rizka.915150148@stu.untar.ac.id,gafary@fikom.untar.ac.id
}

Fakultas Ilmu Komunikasi Universitas Tarumanagara

\begin{abstract}
Brand image is the perception and belief held by consumers, such as those in association and embedded in consumers memories. While the notion of interest is the tendency of someone to pay attention to some activities or activities that are liked by individuals. Tonight Shows a program that has an interest in watching the influence of the appearance of the program, and the host of the Tonight Show. This study uses quantitative survey methods for respondents in Taman Royal 2, Tangerang City. The results showed the effect of brand image on the interest in watching the Tonight Show talkshow program, with the results of the correlation coefficient of 0.732. Based on the results of the coefficient of determination test, found the influence of brand image on the interest to watch the Tonight Show talkshow program has a strong influence that is equal to $53.5 \%$ and T test results obtained that Ho is rejected and $\mathrm{Ha}$ is accepted.
\end{abstract}

Keyword: brand image, talkshow, watching interest

\begin{abstract}
Abstrak
Citra merek (brand image) adalah persepsi dan keyakinan yang dipegang oleh konsumen, seperti yang ada dalam asosiasi dan yang tertanam dalam ingatan konsumen. Sedangkan pengertian minat adalah kecenderungan seseorang yang memperhatikan beberapa aktivitas atau kegiatan yang disukai oleh individu. Tonight Show menjadi program acara yang memiliki minat menonton pada pengaruh tampilan acara, dan pembawa acara Tonight Show. Penelitian ini menggunakan kuantitatif dengan metode survey terhadap responden di Taman Royal 2 Kota Tangerang. Hasil penelitian menunjukkan hasil adanya pengaruh brand image terhadap minat menonton program talkshow Tonight Show yang kuat, dengan hasil koefisien korelasi sebesar 0,732. Berdasarkan hasil uji koefisien determinasi, didapati pengaruh brand image terhadap minat untuk menonton program talkshow Tonight Show memiliki pengaruh yang kuat yaitu sebesar 53,5\% dan didapatkan hasil uji $\mathrm{T}$ bahwa Ho ditolak dan Ha diterima.
\end{abstract}

Kata Kunci: brand image, minat menonton, talkshow

\section{Pendahuluan}

Menurut Morissan (2011) perkembangan yang ada pada media komunikasi saat ini membuat orang di seluruh dunia dapat saling berkomunikasi meskipun tidak bertemu secara langsung, namun tetap dapat berkomunikasi dengan melalui berbagai media komunikasi lainnya. Selain media komunikasi, ada media massa yang seperti siaran penyiaran televisi dan radio yang disebut dengan media penyiaran. Radio dan televisi adalah media penyiaran yang memiliki jumlah penonton dan pendengar dengan jumlah yang paling banyak. 
Stasiun televisi dapat memilih program yang menarik dan program yang memiliki nilai jual untuk ditawarkan yang dapat dikonsumsi oleh masyarakat. Salah satu program televisi yang dapat dikonsumsi dengan positif adalah program talkshow. Sebuah program talkshow akan lebih menarik jika ditonton saat program tersebut tayang secara langsung dalam televisi. Menurut kutipan dari jurnal Muhammad Gafar Yoedtadi (2017) yang mengatakan acara televisi yang disiarkan secara langsung memiliki nilai jual atau ketertarikan masyarakat untuk menonton yang akan lebih tinggi dibanding acara yang diproduksi dengan format rekaman atau tapping.

Dari sisi persiapan jika siaran langsung dilakukan secara detil dan terencana. Penyebabnya adalah acara yang disiarkan secara langsung di televisi tidak memiliki kesempatan untuk melakukan penyuntingan sebagaimana yang dilakukan siaran dengan format rekaman. Berbagai kesalahan dan penyimpangan berpeluang terjadi dalam acara siaran langsung jika ada kata-kata yang digunakan oleh pembawa acara tidak cukup baik. Salah satunya adalah program talkshow yang sering melakukan siaran langsung untuk kebutuhan produksi dan penonton.

Selain membahas tentang siaran langsung yang dilakukan program talkshow dapat diperhatikan juga untuk program talkshow salah satu hal terbesar yang harus diperhatikan adalah citra atau brand image yang menjadi hal utama yang harus diperhatikan dan terus berinovasi untuk hal baru pada tayangan yang dapat menjadi nilai tambah. Brand Image memiliki peranan penting pada sebuah program Talkshow yang dapat menjadi minat untuk menonton. Dengan adanya brand image yang kuat pada suatu program acara di televisi menjadikan tayangan tersebut baik untuk dikonsumsi. Untuk minat menonton dalam program talkshow

Pada penelitian ini peneliti ingin membahas dan mendapatkan pengaruh brand image terhadap judul program minat untuk menonton program talkshow Tonight Show. Program Talkshow Tonight Show adalah sebuah talkshow pada malam hari yang ada pada stasiun televisi NET telah tayang sejak tahun 2013 dan sudah berkali-kali ganti pembawa acara dan juga jam tayang acara. Tonight Show adalah talkshow yang memberikan informasi dan hiburan yang positif. Dengan pembawa acara oleh Vincent Rompies dan Desta Mahendra, dan ada Co-Host yaitu Hesti Purwadinata dan Enzy Storia.

Tonight Show mengundang bintang tamu dari berbagai kalangan entertainment dan diluar entertainment dengan memberikan informasi yang dibutuhkan oleh penontonnya. Tonight Show memiliki visi menjadi program ini adalah "Talkshow yang tidak talkshow" yang dimaksud dengan berbeda dengan talkshow lainnya atau talkshow pada umumnya, wawancara dengan bintang tamu dilakukan dengan berbagai cara dari berbincang dengan bintang tamu, atau dengan games untuk mendapatkan informasi tentang bintang tamunya. Dengan tujuannya untuk menampilkan tayangan yang menghibur dan memberikan informasi dan cara yang berbeda. Maka peneliti ingin mengetahui jika adanya pengaruh brand image yang kuat pada program talkshow Tonight Show maka minat menonton konsumen ada dari beberapa indikator brand image dan minat menonton yang mempengaruhinya.

\section{Metode Penelitian}

Sugiyono (2011) menjelaskan penelitian kuantitatif yaitu sebagai metode penelitian yang berdasarkan filsafat positivism, guna untuk meneliti populasi atau sampel penelitian. Populasi dan sampel pada penelitian kuantitatif harus sesuai dengan target penelitian, dari lokasi penelitian yang telah memenuhi syarat-syarat yang 
Rizka Aprilliani, Muhammad Gafar Yoedtadi: Pengaruh Brand Image Judul Program terhadap Minat Menonton Program Talkshow Tonight Show Net TV

dibutuhkan pada variabel (X) dan variabel (Y) dan kemudian dipilih untuk dijadikan populasi dan sampel penelitian.

Responden dalam penelitian ini dikategorikan dalam beberapa kriteria yang berdasarkan jenis kelamin, usia responden, jumlah responden yang menjadi populasi, alasan minat menonton program Tonight Show, dan pengaruh Brand Image untuk menonton program Tonight Show dan usia yang telah menjadi target usia program talkshow Tonight Show. Berikut merupakan penjelasan karakteristik responden tersebut. Data responden Taman Royal 2 Kota Tangerang berdasarkan jenis kelamin, usia responden, dan jumlah dapat dilihat dalam tabel berikut ini:

\begin{tabular}{lllllll}
\hline \multirow{2}{*}{ No } & \multirow{2}{*}{ Jenis Kelamin } & \multicolumn{5}{c}{ Usia Responden } \\
\cline { 3 - 6 } & & $20-25$ & $26-31$ & $32-37$ & $38-44$ & \\
\hline 1 & Laki - laki & 14 & 10 & 15 & 20 & 59 \\
\hline 2 & Perempuan & 15 & 15 & 10 & 25 & 65 \\
\hline Total & & & & & & 124 \\
\hline
\end{tabular}

Sumber: Olah Data

Pada penelitian ini menggunakan skala likert, dengan menjabarkan pernyataanpernyataan yang sesuai dengan indikator-indikator dari variabel $(\mathrm{X})$ dan (Y) untuk mendapatkan hasil pada penelitian ini yang menggunakan kuesioner. Skala likert adalah perhitungan untuk kuesioner yang menggunakan angka atau simbol dalam kuesioner tersebut, seperti SS (sangat setuju), S (setuju), KS (kurang setuju), TS (tidak setuju), dan STS (sangat tidak setuju).

\section{Hasil Penemuan dan Diskusi}

Hasil dari pengumpulan data dengan survey berdasarkan variabel (X) brand image dan variabel (Y) minat menonton pada tabel berikut ini:

\begin{tabular}{ccc}
\hline \multicolumn{3}{c}{ Variabel (X) Minat Menonton } \\
\hline P1 & Frequency & Percent \\
\hline P2 & 77 & 62,1 \\
\hline P3 & 74 & 59,7 \\
\hline P4 & 77 & 62,1 \\
\hline P5 & 69 & 55,6 \\
\hline P6 & 86 & 69,4 \\
\hline P7 & 100 & 80,6 \\
\hline P8 & 70 & 56,5 \\
\hline P9 & 88 & 71,0 \\
\hline P10 & 76 & 61,3 \\
\hline P11 & 88 & 71,0 \\
\hline & 97 & 78,2 \\
\hline
\end{tabular}




\begin{tabular}{ccc}
\hline & Variabel (Y) Minat Menonton & \\
\hline & Frequency & Percent \\
\hline P1 & 73 & 58,9 \\
\hline P2 & 75 & 60,5 \\
\hline P3 & 94 & 75,8 \\
\hline P4 & 75 & 60,5 \\
\hline P5 & 74 & 59,7 \\
\hline P6 & 84 & 67,7 \\
\hline P7 & 95 & 76,6 \\
\hline P8 & 76 & 61,3 \\
\hline P9 & 90 & 72,6 \\
\hline P10 & 76 & 61,3 \\
\hline P11 & 91 & 73,4 \\
\hline
\end{tabular}

Pengumpulan data berikutnya adalah nilai koefisien korelasi. Menurut Kriyantono, (2014) koefisien korelasi adalah pengukuran yang bertujuan untuk mengetahui dan membuktikan hipotesis hubungan antara variabel dengan interval lainnya. Untuk mengukur tingkat dua variabel itu digunakan Pearson Correlation (Product Moment) atau $\mathrm{r}$ hitung, jika $\mathrm{r}$ hitung lebih besar dari $\mathrm{r}$ tabel maka ada hubungan antara variabel dependen dengan variabel independen.

\begin{tabular}{|c|c|c|c|c|}
\hline $\begin{array}{ll}\quad \text { Mode } \\
1\end{array}$ & $\mathrm{R}$ & R Square & $\begin{array}{l}\text { Adjusted R } \\
\text { Square }\end{array}$ & $\begin{array}{l}\text { Std. Error of the } \\
\text { Estimate }\end{array}$ \\
\hline 1 &, $732^{\mathrm{a}}$ &, 532 & ,532 & 2,970 \\
\hline
\end{tabular}

a. Predictors: (Constant), x_Brand_image

b. Dependent Variabel: y_Minat_menonton

Berdasarkan hasil perhitungan diatas, diketahui nilai koefisien korelasi adalah 0,732 dan didapati bahwa ada hubungan pengaruh brand image dan minat menonton dengan hasil korelasi yang kuat. Nilai koefisien korelasi dikatakan kuat berada di 0,610,80. Nilai koefisien korelasi determinasi pada tabel $\mathrm{R}$ square adalah 0,535 menunjukkan 53,5\% Minat Menonton program Tonight Show dipengaruhi oleh Brand Image, dan sisanya 46,5\% dipengaruhi oleh variabel-variabel lainnya.

Menurut Kriyantono (2014) Uji t dan uji regresi linear sederhana adalah terdapat dua variabel riset yang sudah diketahui mana variabel bebas $\mathrm{X}$ dan yang mana variabel terikat $\mathrm{Y}$, dan nilai-nilai $\mathrm{Y}$ lainnya dapat dihitung berdasarkan suatu nilai $\mathrm{X}$ tertentu. 
Rizka Aprilliani, Muhammad Gafar Yoedtadi: Pengaruh Brand Image Judul Program terhadap Minat Menonton Program Talkshow Tonight Show Net TV

\begin{tabular}{lrrrrr}
\hline Model & \multicolumn{1}{c}{$\begin{array}{c}\text { Unstandardized } \\
\text { Coefficients }\end{array}$} & $\begin{array}{c}\text { Standardized } \\
\text { Coefficients }\end{array}$ & T & \multirow{2}{*}{ Sig. } \\
\cline { 2 - 5 } & \multicolumn{1}{c}{ B } & Std. Error & Beta & & \\
\hline (Constant) & 12,137 & 2,472 &, 732 & 4,909 &, 000 \\
1 x_Brand_image &, 700 &, 059 & & 11,857 &, 000 \\
\hline
\end{tabular}

a. Dependent Variabel: y_Minat_menonton

Berdasarkan data analisis di atas didapati hasil dengan nilai $\mathrm{t}=11,857$ dan tingkat signifikansi $=0,000<0,05$. Maka Ho ditolak dan Ha diterima, dan ada pengaruh signifikan antara brand image terhadap minat untuk menonton program talkshow Tonight Show. Mendapatkan hasil adanya pengaruh brand image terhadap minat menonton mempunyai pengaruh positif yang berarti semakin tinggi brand image, maka semakin tinggi minat untuk menonton. Sedangkan semakin rendah brand image, maka semakin rendah minat untuk menonton. Pada tabel diatas, diketahui nilai parameter regresi linear sederhana antara variabel $\mathrm{X}$ mempengaruhi variabel $\mathrm{Y}$ adalah: $\mathrm{a}=12,137$

$\mathrm{b}=0,700$

Dengan demikian didapatkan nilai regresi linear sederhana sebesar $\mathrm{Y}=\mathbf{1 2 , 1 3 7 + 0 , 7 0 0 X}$

Berdasarkan persamaan di atas, maka diartikan nilai sebesar 12,137 dinyatakan sebagai konstanta fungsi regresi yang menunjukkan, tidak ada kenaikan pada variabel X (brand image), dan pada variabel Y (minat menonton) mengalami peningkatan sebesar 0,700

\section{Kesimpulan}

Hasil penelitian ini adanya pengaruh brand image judul program terhadap minat untuk menonton program talkshow Tonight Show NET TV yang ditunjukan bahwa adanya pengaruh brand image terhadap minat menonton program talkshow Tonight Show yang kuat. Dengan hasil koefisien korelasi sebesar 0,732 dan hasil uji koefisien determinasi, didapatkan pengaruh brand image judul program terhadap minat untuk menonton program talkshow Tonight Show memiliki pengaruh yang cukup kuat yaitu sebesar 53,5\%.

Didapatkan hasil pengaruh yang signifikan antara brand image dan minat untuk menonton karena tingkat signifikan lebih kecil dari 0,05. Pengaruh tersebut positif sehingga semakin tinggi brand image Tonight Show, maka semakin tinggi minat untuk menonton. Jika semakin rendah brand image Tonight Show maka semakin rendah minat untuk menonton. Pada penelitian ini hasil persamaan regresi linear sederhana sebesar $\mathrm{Y}=12,137+0,700 \mathrm{X}$ dan pada uji T didapati bahwa Ho ditolak dan Ha diterima, yang berarti adanya pengaruh yang signifikan antara variabel brand image terhadap minat untuk menonton program talkshow Tonight Show.

\section{Ucapan Terima Kasih}

Ucapan terima kasih dan puji syukur kepada Tuhan Yang Maha Esa karena berkat dan kasih karunianya serta anugerah-Nya penulis dapat menyelesaikan penelitian skripsi ini. Terima kasih kepada keluarga, Fakultas Ilmu Komunikasi 
Universitas Tarumangara, narasumber dan responden yang telah bersedia meluangkan waktunya, dan serta semua pihak yang tidak dapat disebutkan satu-satu yang telah membantu penulis.

\section{Daftar Pustaka}

Bungin, Burhan. (2010). Metode Penelitian Kualitatif. Jakarta: Rajawali Pers.

Kotler dan Keller. (2009). Manajemen Pemasaran Jilid I Edisi 13. Jakarta: Erlangga. Kriyantono, Rachmat. (2014). Teknis Praktis Riset Komunikasi. Jakarta: Kencana Prenada Media Group.

Morissan. (2011). Manajemen Media Penyiaran. Jakarta: Kencana Prenada Media Group.

Slameto. (2010). Belajar dan Faktor-Faktor yang Mempengaruhinya. Jakarta: PT. Rineka Cipta.

Sugiyono. (2011). Metode Penelitian Kuantitatif dan Kualitatif dan R\&D. Bandung: Alfabeta.

Yoedtadi, Gafar, Muhammad,. Pribadi, Adi, Muhammad,. Siswoko, Hari, Kurniawan,. (2017). Proses Produksi Acara Siaran Langsung Televisi Untuk Menghasilkan Avara Yang Layak Tonton. Wacana Jurnal Ilmiah Ilmu Komunikasi. Vol 16 No. 1. 